\title{
БЕЗРАБОТИЦА И СПОСОБЫ ЕЕ СНИЖЕНИЯ В УСЛОВИЯХ РЫНОЧНОЙ ЭКОНОМИКИ В РОССИИ
}

\section{UNEMPLOYMENT AND WAYS TO REDUCE IT IN A MARKET ECONOMY IN RUSSIA}

V. Borobov

Summary. The scientific article examines the current state of employment in the Russian Federation. The analysis of the size of the labor force by age and the level of unemployment in dynamics over the years is quite detailed. The main causes of unemployment are revealed. A set of measures of state support for unemployment, as well as measures to reduce unemployment, is proposed.

Keywords: employment, labor force, active population, disabled people, unemployment, government subsidies, seasonal factors, labor income, government programs, employment, professional development, foreign capital, volunteer activities.

\author{
Боробов Василий Николаевич \\ Д.э.н., профессор, Финансовый университет при \\ Правительстве Российской Федерации \\ vborobov@mail.ru
}

Аннотация. В научной статье рассматривается современное состояние занятости населения в Российской Федерации. Довольно подробно проводится анализ численности рабочей силы по возрасту, уровню безработицы в динамике по годам. Раскрываются основные причины безработицы. Предлагается комплекс мер государственной поддержки безработицы, а также мероприятия по снижению безработицы.

Ключевые слова: занятость, рабочая сила, активное население, инвалиды, безработица, государственные субсидии, сезонные факторы, трудовые доходы, государственные программы, трудоустройство, повышение квалификации, иностранный капитал, волонтёрская деятельность.

источника дохода [1]. Не все граждане, обратившиеся в службу занятости, сразу же признаются безработными и получают пособие по безработице (табл. 1) [5]. В соответствии с пунктом 2, ст. 3, Закона Российской Федерации № 1032-1, «при невозможности органами службы занятости в течение 10 дней со дня их регистрации предоставить гражданам подходящую работу, эти граждане признаются безработными с первого дня предоставления указанных документов» [1].

Анализируя данные, представленные в таблице 1, можно сделать вывод о том, что большинство населения, теряющего трудоустройство, находит новую работу самостоятельно.

Как было выявлено в результате опроса, проведенного в различных регионах России, только 32\% мужчин использует помощь от службы занятости в процессе поиска трудоустройства. Что касается женщин, то здесь положительный ответ на вопрос о том, используются ли услуги государственной службы занятости при поиске работы, дали 49\% респондентов.

В таблице 2 продемонстрированы данные о количестве экономически активного населения в различных федеральных округах. Анализируя эти данные, можно прийти к выводу, что наименьшей степенью безработицы характеризуется Центральный Федеральный округ (ЦФО). А самой большой долей населения, не имеющего 
Таблица 1. Численность и состав рабочей силы в возрасте 15-72 лет

\begin{tabular}{|c|c|c|c|c|c|c|}
\hline & \multirow[b]{2}{*}{ Январь 2020} & \multicolumn{3}{|l|}{2019 год } & \multicolumn{2}{|c|}{01.2020 года к } \\
\hline & & Январь & IV квартал & $\begin{array}{l}\text { В среднем } \\
\text { за год }\end{array}$ & 01.2019 & 12.2019 \\
\hline \multicolumn{7}{|l|}{ млн. человек } \\
\hline Рабочая сила в возрасте15-72 лет & 74699 & 74781 & 75757 & 75226 & -82 & -1058 \\
\hline занятые & 71219 & 71119 & 72267 & 71765 & 100 & -1048 \\
\hline безработные & 3480 & 3662 & 3469 & 3461 & -182 & 11 \\
\hline \multicolumn{7}{|l|}{ В процентах } \\
\hline $\begin{array}{l}\text { Уровень участия в рабочей силе (рабочая } \\
\text { сила к численности населения в возрасте } \\
\text { 15-72 лет) }\end{array}$ & 67,6 & 67,6 & 68,5 & 68 & 0 & $-0,9$ \\
\hline $\begin{array}{l}\text { Уровень занятости(занятые к численности } \\
\text { населения в возрасте15-72 лет) }\end{array}$ & 64,4 & 64,3 & 65,4 & 65 & 0,1 & -1 \\
\hline $\begin{array}{l}\text { Уровень безработицы (безработные } \\
\text { к численности рабочей силы) }\end{array}$ & 4,7 & 4,9 & 4,6 & 5 & $-0,2$ & 0,1 \\
\hline
\end{tabular}

Таблица 2. Численность и состав рабочей силы в возрасте 15-72 лет

\begin{tabular}{|c|c|c|c|c|c|c|}
\hline & \multirow[b]{2}{*}{$\begin{array}{l}\text { Численность } \\
\text { рабочей силы, } \\
\text { млн.человек }\end{array}$} & \multicolumn{2}{|c|}{ В том числе } & \multicolumn{3}{|c|}{ Уровень, в\% } \\
\hline & & занятые & безра-ботные & $\begin{array}{l}\text { участия } \\
\text { в рабочей } \\
\text { силе }\end{array}$ & заня-тости & $\begin{array}{l}\text { безра- } \\
\text { бо-тицы }\end{array}$ \\
\hline Российская Федерация & 74699 & 71219 & 3480 & 67,6 & 64,4 & 4,7 \\
\hline Центральный федеральный округ & 21314,1 & 20661,2 & 652,9 & 71,5 & 69,1 & 3,1 \\
\hline $\begin{array}{l}\text { Северо-Западный федеральный } \\
\text { округ }\end{array}$ & 7509,4 & 7200,4 & 309,0 & 71,7 & 68,7 & 4,1 \\
\hline Южный федеральный округ & 8233,4 & 7752,4 & 482,0 & 67,4 & 63,1 & 5,9 \\
\hline $\begin{array}{l}\text { Северо-Кавказский федеральный } \\
\text { округ }\end{array}$ & 4630,3 & 4121,4 & 508,9 & 65,7 & 58,3 & 11,0 \\
\hline Приволжский федеральный округ & 15942,3 & 14267,2 & 675,1 & 68,5 & 65,2 & 4,5 \\
\hline Уральский федеральныйокруг & 6392,5 & 6084,5 & 309,1 & 70,4 & 66,0 & 4,8 \\
\hline Сибирский федеральныйокруг & 9593,9 & 8941,7 & 652,2 & 67,2 & 61,9 & 6,8 \\
\hline $\begin{array}{l}\text { Дальневосточный федеральный } \\
\text { округ }\end{array}$ & 3331,5 & 3144,8 & 186,7 & 70,9 & 66,8 & 5,8 \\
\hline
\end{tabular}

официальное трудоустройство, характеризуется Северо-Кавказский ФО [7].

Уровень безработицы в России в последние годы был одним из самых низких в новейшей истории. По состоянию на февраль 2020 года уровень безработицы составлял 4,6\%, а в августе 2019 года и всего 4,3\% - что стало рекордом с 1992 года. Динамика безработицы в Российской Федерации с 2010 по 2020 год. согласно методологии МОТ [7].

Как свидетельствует статистика, по итогам 2019 года 7\% экономически активного мужского населения не обладало официальным трудоустройством. При этом среди женщин данный показатель несколько ниже - 6,2\%.

Это позволяет судить о том, что женщины, сталкиваясь с отсутствием денежных средств и источником их получения, соглашаются на низкооплачиваемое трудоустройство. А мужчины, в свою очередь, стремятся найти более высокооплачиваемые места, даже если теряют работу и не имеют накоплений.

В связи с распространением пандемии коронавируса в 2020 году и связанными с этим карантинными мерами большое количество предприятий было вынуждено закрыть или приостановить свою работу. Поэтому значительная часть населения России сталкивается с безработицей.

Максимальный размер пособия по безработице во всех регионах страны (без учета региональных пособий) к концу 2020 года составил 12130 рублей, или сумму, равную минимальной заработной плате. Минимальное пособие осталось на прежнем уровне - от 1500 рублей. Расчёт пособия по безработице зависит от среднего за- 
работка за последние 3 месяца. За первые три месяца пособие выплачивается в размере 75 процентов от средней заработной платы за последние 3 месяца, а за последующие 3 месяца - 60 процентов от той же базы.

Кроме того, допустимы региональные доплаты. Так, в Москве увеличили выплату пособия по безработице до максимальной суммы в размере 19500 рублей. Из них 12130 рублей - это размер льгот на федеральном уровне и еще 7370 рублей - это доплата из бюджета Москвы. Пособие в размере 19500 рублей могут получить работники, проработавшие в 2020 году не менее 60 дней и зарегистрированные по месту жительства в Москве.

Когда кризисные явления в экономике теряют актуальность, ситуация на рынке трудовой силы становится более стабильной. Существует несколько факторов, благодаря которым безработица в России поддерживается на низком уровне для кризисного периода. Во-первых, руководством страны была принята целевая программа, которая позволила десяткам тысяч граждан освоить новую квалификацию, соответствующую потребностям рынка труда, и получить новую работу. Еще одним из направлений государственной программы является оказание комплексной поддержки молодым кадрам, которые только начинают свой трудовой путь, а также другим социально незащищенным категориям населения. В этом направлении используется сразу несколько мер:

- предоставление субсидий предприятиям, активно трудоустраивающим молодых специалистов;

- предоставление адресной финансовой поддержки молодым кадрам, переезжающим в иные регионы для поступления на работу;

- оказание содействия в нахождении нового места работы инвалидам, а также родителям, имеющим трёх и более детей;

- проведение программ по повышению квалификации и переподготовке для женщин, пребывающих в отпуске по уходу за ребенком;

- иные меры, регламентируемые Постановлениями российского Правительства [7].

Отметим, что деятельность государства по снижению безработицы благотворно сказывается на состоянии экономики. Как свидетельствует статистика, формируемая органами занятости, количество лиц, обращающихся за поддержкой в связи с потерей места работы и получающих всю необходимую помощь, растет год от года.

Однако здесь нельзя не отметить, что не каждый случай потери работы фиксируется в статистике. Широкое распространение приобрела «скрытая безработица». Она может проявляться, например, в переводе сотрудников компании на сокращенный режим рабочего вре- мени и соответственно сокращении заработной платы. Дать хотя бы приблизительную оценку масштабам распространения «скрытой безработицы» невозможно. Однако даже имеющихся в свободном доступе данных достаточно для того чтобы судить, что от «скрытой безработицы» страдает в несколько раз больше граждан, чем официально признано статистикой в качестве безработных. Остановимся подробнее на основных причинах безработицы.

Современная экономика характеризуется наличием сразу нескольких тенденций, негативно сказывающихся на занятости населения:

1. Автоматизация. Производственные предприятия все больше пользуются автоматизацией, вследствие которой ту работу, которую раньше выполнял человек, делает машина. Из-за этого объём доступных рабочих мест уменьшается, люди высвобождаются. И даже переподготовка, которую предлагают предприятия увольняемым лицам, не способствует их новому трудоустройству.

2. Кризисные явления в экономике. В период спада В экономике предприятиям не требуется крупный штат работников, из-за чего происходят сокращения.

3. Сезонные факторы. В некоторых сферах бизнеса деятельность носит ярко выраженный сезонный характер. Некоторые предприятия умеют справляться с этим, диверсифицируя свою работу и перераспределяя сотрудников между подразделениями. Однако существует и такой бизнес (как правило, малый), который нуждается в сотрудниках только 3-4 месяца в году, а все остальное время неспособен предложить трудоустройство.

4. Низкие трудовые доходы. В России и других странах получает распространение такое уникальное социально-экономическое явление, как бедность работающего населения. Его суть заключается в том, что даже те семьи, где работает два и более человека, не могут финансировать обязательные расходы: питание, ЖКХ, транспорт, одежду [2].

В современной экономической науке отсутствует единая точка зрения по вопросу, что выступает главной причиной роста безработицы. Экономисты разных направлений обладают отличающимися взглядами на проблему.

Специалисты, которые являются приверженцами классической школы, считают, что безработица возникает из-за отсутствия гибкости в начислении заработной платы для сотрудников. Они полагают, что существует значительная прослойка сотрудников, размер трудовых доходов которых не соответствует вносимому ими вкладу в успех компании. 
Экономисты, придерживающиеся концепции Кейнса, заявляют о том, что увеличение заработной платы провоцирует повышение заинтересованности предприятий в привлечении новых работников. Этот процесс, в свою очередь, сказывается на том, что потребность компании в обновлении персонала растёт.

Для более точного анализа статистических данных о безработице необходимо рассмотреть следующие факторы.

- Экономическая специализация региона. Россиягосударство, которое характеризуется большой площадью. В её состав входят регионы, которые значительно отличаются друг от друга по климатическим и иным условиям. В некоторых из субъектов Федерации прибыльными являются только конкретные виды бизнеса. Вследствие этого люди, являющиеся специалистами в непрофильных для своего региона сферах, не имеют шанса на трудоустройство.

- Практика неофициального трудоустройства. Это значит, что сотрудники принимаются на работу либо вообще без трудового соглашения, либо с его оформлением, но с указанием в документе существенно заниженной заработной платы. Изза этого статистическая отчетность, передаваемая компанией в государственные органы, не отражает реального положения дел.

Необходимо обратить внимание на тот факт, что ведущая роль в деятельности по уменьшению безработицы принадлежит государственным институтам. Именно от эффективности их функционирования, зависит снижение доли населения, не имеющего работу. В связи с проведёнными исследованиями, можно сделать конкретные выводы. Для уменьшения безработицы в России помогут следующие мероприятия:

1. Стимулирование официального трудоустройства экономически активного населения. Поскольку, некоторая часть экономически активного населения не имеет официального трудоустройства по причине неудобного графика, необходимости длительного присутствия на работе. Представляется, что здесь может помочь программа уменьшения длительности рабочей недели до четырех дней. Такое решение позволит снизить нагрузку на население, предоставить людям больше времени для отдыха.

2. Расширение возможностей для трудоустройства лиц, являющихся наименее защищенными в социальном плане (инвалидов, многодетных родителей, молодых специалистов).

3. Предоставление государственных субсидий (и иных мер поддержки) компаниям, которые соглашаются на расширение штата, приглашение новых специалистов дополнительно к уже имеющимся.

4. Увеличение финансирования, направляемого на выплату пособий по потере работы. При реализации этого мероприятия государству следует проявлять осторожность и придерживаться баланса. Если выделить излишнее финансирование и сделать пособия по потере работы сопоставимыми со средней заработной платой, то население может утратить стимул для поиска работы.

5. Создание системы комплексного бесплатного переобучения, совершенствования квалификации.

6. Развитие международного сотрудничества. Благодаря международной активности российские специалисты становятся более привлекательными для зарубежных работодателей [3].

Правительству Российской Федерации нужно вести комплексную деятельность по предупреждению и уменьшению безработицы. Для этого необходимо:

- оказывать поддержку организациям, которые расширяют деятельность и увеличивают штат сотрудников (например, за счет налоговых преференций, выдачи кредитного финансирования по льготным ставкам);

- способствовать вовлечению иностранного капитала в российскую экономику, применению передовых разработок других стран на благо местных предприятий;

- предоставлять широкие меры государственной поддержки тем компаниям, которые не только увеличивают число мест для трудоустройства, но и ведут инновационную деятельность, которая позволяет расширять сферу интересов бизнеса, делать его более устойчивым и прибыльным;

- оказывать финансовую и организационную помощь гражданам, меняющим место жительства для трудоустройства (например, предоставлять место кратковременного пребывания, подъемные средства для обзаведения хозяйством, льготы по устройству детей в учреждения дошкольного и школьного образования);

- способствовать активизации волонтерской деятельности;

- решить проблему, связанную с нелегальными мигрантами из иных стран (преимущественно Средней Азии).

Стоит отметить, что граждане других государств, нелегально прибывающие в Российскую Федерацию с целью получения трудоустройства, представляют собой серьёзную проблему для национального рынка труда. Они занимают вакансии, которые могли быть отданы местному населению. Поэтому, введение крупных 
штрафов для предприятий, уличенных в привлечении нелегальных мигрантов из иных государств, будет способствовать расширению числа доступных вакансий для граждан России [4].

Таким образом, государственные институты, существующие в Российской Федерации, должны проводить активную и скоординированную деятельность, направленную на уменьшение безработицы в различных социальных группах.

Подводя итоги, можно сделать следующие выводы. Уровень безработицы в России в последние годы был одним из самых низких в новейшей истории. Однако изза распространения пандемии коронавируса в 2020 году и связанных с этим карантинных мер большое количество предприятий были вынуждены закрыть или приостановить свою работу. В связи с этим значительная часть населения России сталкивается с безработицей.

Для решения проблем безработицы необходимы совместные действия государства, органов местного самоуправления, предпринимателей. Только взаимная поддержка и выполнение поставленных целей и задач дадут положительный результат в этот сложный для России период.

\section{ЛИТЕРАТУРА}

1. Закон РФ от 19.04.1991 № 1032-1 (ред. от 24.04.2020) «0 занятости населения в Российской Федерации»

2. Борисов Е.Ф. Основы экономики.-М.: Дрофа, 2017.- 416 с.

3. Гусейнов Р.М., Семенихина В.А. Макроэкономика: Учебное пособие для бакалавров. — М.: Омега-Л, 2017.— 254 с.

4. Горина К.В. Занятость населения как отражение уровня качества жизни жителей территории // Зап. Забайкальского отд-ния Рус. геогр. 06-ва. - 2016. C. $173-178$.

5. Макарова М.Н., Воронина Л.Н., Третьяк А.Н. Оценка влияния компонентов качества занятости на смертность трудоспособного населения // Динамика и инерционность воспроизводства населения и замещения поколений в России и СНГ. Т. 2: Демографический потенциал регионов России и СНГ: динамика роста и инерционность изменений. — Екатеринбург: Ин-т экономики Ур0 РАН, 2016. — С. 106-113.

6. Миндлин Ю.Б. Формирование основных мероприятий по совершенствованию политики московской области в сфере привлечения трудовых ресурсов // Микроэкономика. 2009. № 2. С. 131-138.

7. 0 занятости населения Российской Федерации. [Электронный ресурс]. Официальный сайт Федеральной службы государственной статистики [Электронный ресурс]. 